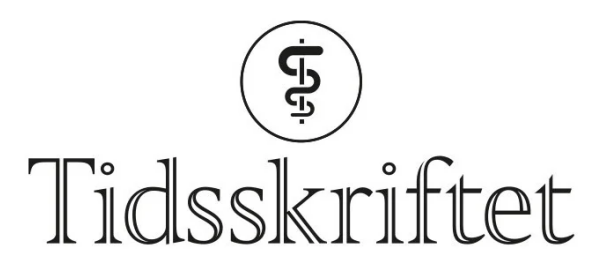

DEN NORSKE LEGEFORENING

\title{
Jacob Birger Natvig
}

MINNEORD

ERLEND HEM

TONJE INGARSDOTTER HELGESEN

ELISABETH T. SWÄRD

PER E. BØRDAHL

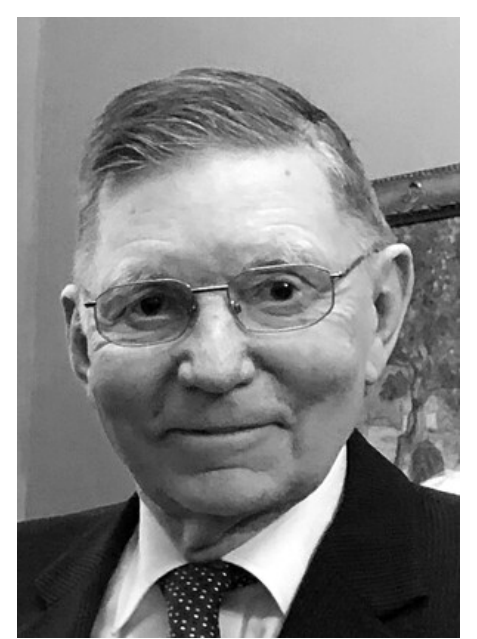

Jacob Birger Natvig døde i sitt hjem på Bekkelagshøgda i Oslo langfredag 2. april, etter en tids sykdom, 86 år gammel. En pioner i norsk medisin er gått bort.

Han ble cand.med. ved Universitetet i Oslo i 1959. Etter turnus- og militærtjeneste arbeidet han i Bergen og tok doktorgraden på en avhandling om gammaglobulin i 1966. Etter et år ved The Rockefeller University i New York ble han i 1967 første overlege ved Rikshospitalets institutt for generell og revmatologisk immunologi. I mange år var han den mest siterte norske biomedisinske forskeren, med en lang rekke artikler i prestisjetunge, internasjonale tidsskrifter.

Han var sterkt knyttet til Rikshospitalet, som i alle år ble hans arbeidsplass. I 1978 ble han administrerende direktør, en stilling han hadde i åtte år. Men han forlot ikke immunologien helt. Også i årene som direktør holdt han kontakt med det immunologiske miljøet, deltok i prosjektmøter, reiste på konferanser og publiserte et stort antall 
vitenskapelige bidrag. I 1986 vendte han tilbake til arbeidet som forsker og lærer på heltid og var professor ved Universitetet i Oslo inntil pensjonsalder. I 1974 ble han portrettert i Aftenposten og spurt om hvilke egenskaper en forsker bør ha. Svaret kom kort og konsist: "Utholdenhet og fantasi». Utholdenhet var ikke det minst viktige. «Det som bringer resultater er at man satser helt og fullt.» Og det levde Jacob etter i alle år, som forsker, som administrator og i menighetsarbeidet som hele tiden var så viktig for ham.

Jacob var en av grunnleggerne av faget medisinsk immunologi i Norge. Han hadde en lang rekke verv. Selv verdsatte han høyt arbeidet i International Union of Immunological Societies. Hans lærebok i medisinsk immunologi, som han skrev sammen med Morten Harboe, var pensum for norske medisinstudenter i over 20 år. Den ble oversatt til tysk, spansk og japansk. I 2009 ble han Ridder av 1. klasse av St. Olavs Orden for sin innsats for norsk medisinsk forskning og for bedring av medisinske forhold i utviklingsland.

Jacob var i 2002 en av grunnleggerne av Stiftelsen Nasjonalt medisinsk museum, der han var leder i mange år. Med en formidabel arbeidskraft, et uslitelig humør og en egen evne til å knytte forbindelser, bidro han til stiftelsens vekst. Det var derfor helt naturlig at han i 2019 ble utnevnt til stiftelsens hittil eneste æresmedlem.

Våre tanker går til Jacobs kone gjennom 6o år, Harriet, og hans store familie.

På vegne av Stiftelsen Nasjonalt medisinsk museum

Publisert:3. mai 2021. Tidsskr Nor Legeforen. DOI:10.4045/tidsskr.21.0281

(C) Tidsskrift for Den norske legeforening 2023. Lastet ned fra tidsskriftet.no 26. april 2023. 